\title{
TITLE:
}

\section{A New Method for Chemical Instability with Diffusion}

$\operatorname{AUTHOR}(S)$ :

川崎, 恭治; Kim, S.K.

\section{CITATION:}

川崎, 恭治 ...[et al]. A New Method for Chemical Instability with Diffusion. 物性研究 1978, 29(6): F45-F45

ISSUE DATE:

1978-03-20

URL:

http://hdl.handle.net/2433/89485

RIGHT: 
A New Method for Chemical Instability with Diffusion

$$
\begin{aligned}
& \text { 九大・理 川 } \text { 崎 恭 治 } \\
& \text { テンプル大化学 }
\end{aligned}
$$

化学反応系を記述する方程式は一般に反応をあらわす非線型項と空間的拡散の項を同 時に含んで居るためにとり扱いが困難である。しかし空間的に一様なゆらぎが最も不安 定になる場合には非線形性と拡散とを近似的に分離し得る方法があるので，それについ て報告した。方法の基礎は, 最近レーザー模型 ${ }^{1)}$ や TDGL 系 ${ }^{2)}$ において不安定点から のゆらぎの成長に対して発展されたスケーリング理論或は特異的捸動論である。最初体 系が不安定点から僅かにはつれれた状態にあったとする。不安定性のために時間がたつと 共にズレは増大するが同時に長波長成分にズレが集中する。そこで今非線型項を無視し た方程式系（これをL系と名づける）と拡散項を無視した方程式系（これを $\mathrm{N}$ 系と名 うける）を考える。N系は多くの場合解く事ができ，この解を用いて $\mathrm{N}$ 系で更に非線 形項を無視した方程式系の解 A から $\mathrm{N}$ 系の解 $\mathrm{S}$ への時間的・空間的に局所的な変換 $\mathrm{T}$ を作ることができる： $\mathrm{S}(\boldsymbol{r}, \mathrm{t})=\mathrm{T} \cdot \mathrm{A}(\mathrm{r}, \mathrm{t})$ 。この方法では先づ初期関数 $\mathrm{S}(\mathbf{r}, 0)$ が 与えられた時, 逆変換で $\mathrm{A}(\mathrm{r}, 0)$ を作る : $\mathrm{A}(\mathrm{r}, 0)=\mathrm{T}^{-1} . \mathrm{S}(\mathrm{r}, 0)$ 。次に $\mathrm{A}(\mathrm{r}, \mathrm{t})$ の時間発展は方程式系 $L$ で記述される。最後に元の方程式系の解 $\mathrm{S}(\mathrm{r}, \mathrm{t})$ を求めるに は変換 $\mathrm{T}$ 適用する: $\mathrm{S}(\mathbf{r}, \mathrm{t})=\mathrm{T} \cdot \mathrm{A}(\mathrm{r}, \mathrm{t})$, この方法を Schlögl モデルに応用し应散 とsaturation効果を同時にとり入れる事ができる事を示した。この方法は $\mathrm{t}=\infty$ でも正 しい答を与えるが，最終段階でそこに近づく仕方がどれ程正しいかについて問題がある ので，そこを調べることは今後に残されている。この研究は近く Journal of Chemical Physics に発表予定である。

\section{参 考 文 献}

1）鈴木増雄 インド国際理論物理学会での報告

2) K. Kawasaki, M. C. Yalabik, J. D. Gunton, Phys. Rev. A, (1977 年 11月) 